\title{
THE USE OF MODAL AUXILIARY VERBS IN HOROSCOPE: A CORPUS-BASED STUDY
}

\author{
Yvonne Soon Chiin LING \\ SMK Beladin, 94950 Pusa, Betong \\ yvonneling87@hotmail.com
}

Manuscript received 10 May 2016

Manuscript accepted 7 November 2016

\begin{abstract}
Horoscope is a regular content in women's magazine. Horoscope contains modal auxiliary verbs which are used to establish familiarity and relationship. As modal auxiliary verbs are among the most problematic grammatical items in teaching and learning of English, horoscope can be used as authentic teaching and learning material. The present study is a corpus-based approach which seeks to investigate word frequency and examine the use of modal auxiliary verbs in the horoscope section of English women's magazines. Three bestselling Malaysian female magazines from the year of 2011 to 2013 were analysed. The corpus consists of horoscope from 108 magazine issues. The data were analysed using AntConc and Editpad Pro to generate frequency lists and concordance lines. Both the frequency lists and the concordance lines were analysed to discover the use of modal auxiliary verbs in horoscope. It was found that the most frequent modal auxiliary verbs used in horoscope are will and may to express prediction and possibility. The least used modal auxiliary verbs are should and must which are modals of necessity and obligation. The pronoun you is the most frequent lexis in every horoscope entry. Based on findings from this study, horoscopes can be used to teach the modal auxiliary verbs in addition to prescribed Malaysian textbooks.
\end{abstract}

Keyword: corpus linguistics, corpus-based, horoscope, modal auxiliary verbs

\section{Introduction}

Horoscope, favoured by the contemporary mass media around the world, is a regular content in women's magazine. It appears in the content page under the headings such as "in every issue" or "regulars". A quick survey by Chang (2002) shows that horoscopes appear in the printed media such as newspapers and in at 
least 25 English magazines sold in Malaysia. A quick survey performed for this current research indicated that none of the men's magazine contains horoscopes. Most women's magazines in Malaysia have a horoscope section but none of men's magazine contains horoscopes. Horoscope is a forecast of a person's future based on the zodiac. Horoscope is personal yet it addresses the general readers.

Horoscopes consist of manageable short text which can be easily read by learners of all ages. They are less formal texts and have their own lexical characteristics. Horoscopes in magazines are usually rich in pronouns, modal auxiliary verbs and idiomatic language. They share similar text structures, raise similar topics and utilise particular linguistic devices. Engler (2003) found that auxiliary verb patterns are usually used in horoscope pages in women's magazine. Auxiliary verbs are used to establish familiarity and relationship between the writer and the reader. Auxiliary verbs also identify the mood of the horoscope entry which includes doubt, possibility or obligation (Engler, 2003).

Students can learn modal auxiliary verbs through authentic materials such as horoscopes. Martinez (2002) defines authentic materials as real-life materials that students encounter in everyday life but they were not created for educational purposes. When teachers use authentic materials, students are exposed to the language used in real life (Guariento \& Morley, 2001). Besides, authentic materials promote meaningful learning (Tomlinson, 1998). Students are more motivated to learn English language because they find learning the language more meaningful when they see the language used in real life. Students are able to relate to the teaching material and learn modal auxiliary verbs better. Horoscopes are rich in modal auxiliary verbs (Watts, 1984), so they can be used in the language classroom to teach modal auxiliary verbs. They are a good textual source to teach modal auxiliary verbs as they occur in natural contexts (McCarthy \& Carter, 2014).

Modal auxiliary verbs are among the most problematic grammatical item in the teaching and learning of English as a second language (Khojasteh \& Reinders, 2013; Mukundan \& Khojasteh, 2011; Vethamani, Umi Kalthom Abd Manaf, \& Omid Akbari, 2010). One of the problematic grammatical items faced by Malaysian ESL learners is the correct use of modals (Hughes \& Heah, 1993). Students in both urban and rural areas have difficulty in using verb forms including modal auxiliaries. This is evident in an error analysis of Form Four English composition by Rosli and Edwin (1989) and this is further supported by Ferris (2002) who stated that verb forms related to modal auxiliaries are problematic to both L1 and L2 speakers. In standard formal English, the same modal can express different notions, ranging from probability through permission to obligation.

The complexity of modal auxiliary verbs causes confusion among learners. Modal auxiliary verbs express events or actions which are in the mind and it may or may not happen in the future (Hoye, 1997). Although there are only a few modal auxiliary verbs, they share similar core meanings, making them confusing to the users. Thompson (2002) states that modal auxiliary verbs are a complex entity that cannot be easily segmentalised into meaningful chunks for information to be presented to learners. As a result, the complex English modal auxiliary system becomes a problem in the teaching and learning of English (Vethamani et al., 2010). Modal auxiliary verbs are an important part of grammar and semantics in English. 
Language users express their intentions, emotion and expectancy to influence other's decisions through the use of modals (Liao \& Liao, 2009). Thus, learners need to be clear about the meaning and use of modal auxiliary verbs to enable them to communicate effectively in the language. Teachers, therefore, play an important role in teaching and explaining modal auxiliary verbs to students.

Horoscopes would also be an interesting teaching material because the content is related to the readers' daily lives and concerns. The common topics discussed in horoscopes are things that apply to people in daily lives such as love, relationship, friendship, marriage, family, health, work, luck, self-control, selfreflection, spending money, going out, change and fine food and drinks (Zareva, 2013). The horoscope columns aim to flatter readers, give advice, warn, reproach and give predictions about future events. A horoscope text is an attractive resource for language learning because it is easy to read. The text consists of simple sentence constructions as it is targeted at a general audience. The use of positive emotion words flatters the reader (McLoughlin, 2000). When students see the relevance of materials in their lives, they are more motivated to learn the language.

Horoscopes are fun and engaging to read, making it a good catalyst for discussion and self-expression. Besides, they also contain extensive use of modal auxiliaries which is the feature of interest to this study. In view of the important potential of horoscopes as a language teaching material, there is a need for a thorough investigation of the language used in horoscopes. Thus, this current study will focus on the analysis and the use of modal auxiliary verbs in horoscopes and discuss the contribution of horoscopes to the teaching materials teachers can use in the language classroom to teach modal auxiliary verbs.

In view of the objective mentioned, this study attempts to answer the following research questions:

1. What is the most frequent lexis used in horoscopes in the three women's magazines?

2. What are the modals auxiliary verbs used in horoscopes in the three women's magazines?

3. What is the use of the modal auxiliary verbs in the three women's magazine?

\section{Literature Review}

\section{Corpus Linguistics}

Corpus linguistics is a method of carrying out linguistic analysis where naturally occurring text is analysed. It takes into account language usage that is collected and analysed in the corpora (Wynne, 2005). The corpus approach is empirical, as it analyses the actual patterns of language used in natural texts (Biber, Conrad, \& Reppen, 1998). Corpus linguistics can be either corpus-driven or corpus-based. Corpus-driven linguistics aims to discover facts about language, free from the influence of the existing theoretical framework. The observed patterns in the corpus data are used as a basis to derive insights about language. The corpus itself is therefore the sole source of hypothesis about language (Tognini-Bonelli, 2001). On 
the other hand, corpus-based linguistics uses corpus data to explore a theory or hypothesis aiming to validate it, refute it or refine it (Tognini-Bonelli, 2001). This study is corpus-based as it starts with a pre-existing theory formulated from previous researches (Chang, 2000; Zareva, 2013) that have indicated the high occurrences of modal auxiliary verbs in horoscopes. Hence, this study looks at modal auxiliary verbs that are present in horoscopes.

\section{Modal Auxiliary Verbs}

In English, there are nine modals verbs which are the central modal auxiliary verbs. They are will, would, can, could, may, might, shall, should and must (Biber, Conrad, \& Leech, 2002; Hoye, 1997). In addition to the nine central modals, there is a small group of "marginal modals" - ought to, need to, used to, need which can in some ways behave like modals and in some ways like main verbs (Kennedy, 2002; Quirk, Greenbaum, Leech, \& Svartvik, 1985). There is also a small group of expressions known as "semi-modals" which also function as modals, namely, (had) better, (have) got to, be about to, be going to and be supposed to (Kennedy, 2002).

The occurrence of modal verbs is influenced by text types. Will has been found to be the most frequent of the central modal verbs, while will, would, can and could occur a lot more often than other central modals (Biber, Conrad, Leech, \& Finegan, 1999; Kennedy, 2002). However, the distribution of modals differs between written and spoken texts and context (Vine, 2004). A search of the one-million word Wellington Corpus of Spoken New Zealand English (WSC), shows that the modal would is the most frequent central modal, followed by will, can and could. When focusing on transactions and meetings in the WSC, will rather than would is the most frequent central modal. Besides, modal verbs carry important information about the sender's attitude to the message and other interpersonal meanings (McCarthy, 1991). Therefore, the modals in the corpus of this study will be explored and analysed. Quirk et al. (1985) categorised modals into three classes according to their similar and overlapping meanings. Modals that show permission, ability, possibility are can, might, could and may. Should and must show necessity and obligation while shall, would and will show prediction or volition.

\section{Studies on Modal Auxiliary Verbs}

Studies show that the distribution of modal auxiliary verbs is determined by text types. A study on relative distribution of core and epistemic uses of modals in British English found that the four most frequent modals were will, would, can and could (Coates, 1983). Will represented 22\% of all the modals found. Quirk et al. (1985) discovered that the frequency of individual modals varied greatly in the Brown, LOB and SEU corpora. Modals were more frequent in spoken than in written English. The four most frequent modals were will, would, can, and could.

Kennedy (2002) in his study on the variation of the distribution of modal verbs in the British National Corpus (BNC) found that $1.45 \%$ or 1457,721 of the word token in BNC are tagged as modals. Will, would, can and could account for $72.7 \%$ of all the modal verb tokens. The most frequent modal was will; accounting 
for almost $23 \%$ of all modal tokens in the corpus. Results also showed that modals occurred in greater frequency in spoken texts than in written texts.

A comparative analysis of BNC and a German textbook series by Romer (2004) found that there were huge discrepancies between the use of modal auxiliaries taught in school and in authentic English. There were overuse of the modals will/'Il, can and must and underuse of would/'d, could, should and might. There were also differences in meaning distribution of each modal verb. Percentage of can and could expressing ability in the text book $(52.5 \%$ and $78.3 \%)$ was much higher than in the BNC (36\% and $34 \%)$. Could in BNC was more frequently used to express possibility than ability. A similar corpus-based comparative analysis of modal auxiliary verbs in prescribed Malaysian English textbooks with the BNC carried out by Mukundan and Khojasteh (2011) found mismatch between frequency order in the textbook corpus and the BNC. Will, would, can and could were considered the most frequent modals in BNC.

Previous corpus based researches on modal auxiliary verbs were focused on textbooks while researches on horoscopes leaned towards stylistic analysis on the representation of the women. Women's magazine has been the subject of many studies but there are limited studies on horoscope. This present study focuses on the modal verbs used in horoscopes using the corpus approach and will discuss how horoscopes can be used in the language classroom to teach modals. The incorporation of authentic materials rich in modal auxiliary verbs in the language classroom will expose students to actual usage of modal auxiliary verbs. The most frequently used modals would be identified from the analysis and this information can help teachers decide which modals to be dealt with first in teaching. Besides, horoscopes would provide plenty of opportunities for learners to read and use modal auxiliary verbs.

\section{Methodology}

This corpus-based research was designed to investigate the frequent lexis, analysing modal auxiliary verbs and the use of modal auxiliary verbs in horoscope. The qualitative data of the concordance analysis will complement the quantitative data from the frequency list.

\section{Data Description}

For this study, the data is a corpus which is compiled using 108 issues of three magazines, namely, CLEO, Female and the Malaysian Women's Weekly from the year 2011 to 2013. All three magazines provide astrological descriptions and advice for each star signs: Capricorn, Aquarius, Pisces, Aries, Taurus, Gemini, Cancer, Leo, Virgo, Libra, Scorpio and Sagittarius.

As the corpus was intended to be a mini corpus, one which is manageable, 108 magazines were selected. The total size of the corpus examined in this study is 110,111 words. There is no minimum size for texts to be considered a corpus (Reppen \& Simpsons, 2002; Sinclar, 2005). The magazines were chosen due to its popularity among students and affordability in the market. Magazines from years, 
2011 to 2013 were chosen as they were the latest publication three years from when the research was conducted and the corpus would reflect current issues and contemporary usage of modal auxiliary verbs.

Table 1

Corpus data

\begin{tabular}{lccc}
\hline Magazine & $\begin{array}{c}\text { Number of years in } \\
\text { publication }\end{array}$ & $\begin{array}{c}\text { Number of } \\
\text { issues sampled }\end{array}$ & $\begin{array}{c}\text { Total word } \\
\text { tokens }\end{array}$ \\
\hline $\begin{array}{l}\text { CLEO Malaysia } \\
\text { The Malaysian }\end{array}$ & 19 & 36 & 57654 \\
$\quad \begin{array}{l}\text { Women's Weekly } \\
\text { FEMALE }\end{array}$ & 14 & 36 & 28173 \\
\hline & 40 & 36 & 24284 \\
\hline
\end{tabular}

\section{Instruments}

For this study, three computational tools, namely, CLAWS tagger, AntConc and EditpadPro were used. CLAWS, a part of speech tagger, was later used to tag the lexis found in the data. The data in the form of .txt was tagged using $\mathrm{C7}$ tagset by Lancaster University CLAWS which has over 160 tags. Editpad Pro is a text editor that can be used to clean up texts. It is supported with powerful regular expressions. The regular expression $\backslash S^{*}\left[{ }^{\wedge} \mathrm{VM}\right] \backslash S^{*}$ was used to identify the modal auxiliary verbs in the data and other unrelated words were eliminated. AntConc was used to generate frequency list for frequent lexis and frequent modal auxiliary verbs and generate concordance.

\section{Results and Discussion}

\section{Frequent Lexis in Horoscope}

The analysis of data collected from the horoscope section of three magazines reveals a similar pattern in word lexis. WordList function in AntConc sorted the frequent words in descending frequency order. For all three magazines, the highest frequency is shown by the pronoun you (Table 2).

Table 2

Frequency count of frequent lexis

\begin{tabular}{ccccccccc}
\hline \multicolumn{3}{c}{ CLEO } & \multicolumn{3}{c}{$\begin{array}{c}\text { Women's } \\
\text { Weekly }\end{array}$} & \multicolumn{3}{c}{ Female } \\
\hline Lexis & Frequency & $\%$ & Lexis & Frequency & $\%$ & Lexis & Frequency & $\%$ \\
\hline you & 2891 & 5.01 & you & 1394 & 4.95 & you & 1138 & 4.69 \\
your & 2337 & 4.05 & the & 967 & 3.43 & to & 788 & 3.24 \\
and & 2147 & 3.72 & your & 870 & 3.09 & your & 702 & 2.89 \\
the & 1790 & 3.10 & to & 855 & 3.03 & it & 694 & 2.86 \\
to & 1729 & 3.00 & and & 835 & 2.96 & and & 658 & 2.71 \\
\hline
\end{tabular}




\begin{tabular}{ccccccccc}
\hline will & 1420 & 2.46 & a & 689 & 2.45 & for & 646 & 2.66 \\
be & 1014 & 1.76 & of & 528 & 1.87 & the & 634 & 2.61 \\
a & 878 & 1.52 & be & 489 & 1.74 & a & 546 & 2.25 \\
'Il & 698 & 1.21 & in & 329 & 1.17 & go & 460 & 1.89 \\
of & 649 & 1.13 & will & 322 & 1.14 & days & 421 & 1.73 \\
\hline
\end{tabular}

For CLEO, the pronoun you has the highest frequency 5.01 per cent of total occurrences in the CLEO corpus data. The second most frequent word is the possessive adjective your accounting for 4.05 per cent. For Women's Weekly, the word with the highest frequency is the pronoun you constituting 4.95 per cent of total occurrences in the Women's Weekly corpus data. The second most frequent word is the article the which constitutes 3.43 per cent of total occurrences. For FEMALE, the word with the highest frequency is the pronoun you with 4.69 per cent in the total occurrences in the Female corpus data. The second most frequent word is the infinitive marker to representing 3.24 per cent of the total occurrences.

In horoscopes, the writer communicates with the reader through a one-way simulated conversation in written form. Various ways are used by the writer to create this interactive discourse. The high usage of pronoun you shows that it is deliberately used to address each of the potential readers personally. The second personal pronoun you has a wide range of potential reference. You could be used as a singular or plural reference and a specific or a generalised reference. Despite the language vagueness, horoscopes attempt to motivate readers and persuade them to change their negative aspects. By using the pronoun you, the writer seems to be communicating directly with the readers by generating a feeling of uniqueness. As a result, readers feel that the text is addressed at them and this makes them feel important and unique. Therefore, the writer appeals to the readers in general and also speaks to the reader specifically. With this power, horoscope writers are able to give readers advice and motivation.

\section{Frequent Modal Auxiliary Verbs in the Horoscope of Three Magazines}

The data of the three horoscopes collected and analysed show different distribution of frequency in modal auxiliary verbs. Frequencies can show us words or structures that are prominent in a language (Romer, 2004). Some modal verbs are used far more frequently than others. The most frequent modal verbs for all three magazines is the modal verb will. All the central modal verbs (will, would, can, could, shall, should, may, might and must) are present in all three magazines. The frequency of modal verbs for each magazine is shown in the Tables 3 and 4.

Table 3

Distribution of modal auxiliary verbs in three magazines

\begin{tabular}{ccccccc}
\hline Modal & \multicolumn{2}{c}{ CLEO } & \multicolumn{2}{c}{ Women's Weekly } & \multicolumn{2}{c}{ Female } \\
\cline { 2 - 7 } $\mathbf{s}$ & $\begin{array}{c}\text { Frequenc } \\
\text { y }\end{array}$ & $\begin{array}{c}\text { Percentag } \\
\text { e }\end{array}$ & $\begin{array}{c}\text { Frequenc } \\
\text { y }\end{array}$ & $\begin{array}{c}\text { Percentag } \\
\text { e }\end{array}$ & $\begin{array}{c}\text { Frequenc } \\
\text { y }\end{array}$ & $\begin{array}{c}\text { Percentag } \\
\text { e }\end{array}$ \\
\hline will & 2118 & 76.46 & 597 & 56.59 & 248 & 46.97
\end{tabular}




\begin{tabular}{ccccccc} 
may & 223 & 8.05 & 162 & 15.36 & 127 & 24.05 \\
could & 194 & 7.00 & 74 & 7.01 & 16 & 3.03 \\
should & 31 & 1.12 & 68 & 6.45 & 34 & 6.44 \\
must & 17 & 0.61 & 13 & 1.43 & 1 & 0.19 \\
would & 12 & 0.43 & 8 & 0.76 & 19 & 3.60 \\
might & 11 & 0.40 & 23 & 2.18 & 23 & 4.36 \\
shall & 1 & 0.04 & 0 & 0 & 0 & 0 \\
\hline Total & 2770 & 100.00 & 1053 & 100.00 & 528 & 100.00 \\
\hline
\end{tabular}

Table 4

The distribution of modals in corpus

\begin{tabular}{cccc}
\hline Modals & Frequency & Percentage & Occurrence per ten thousand words \\
\hline will & 2963 & 2.69 & 269 \\
may & 512 & 0.46 & 46 \\
can & 331 & 0.30 & 30 \\
could & 284 & 0.26 & 26 \\
should & 133 & 0.12 & 12 \\
might & 57 & 0.05 & 5 \\
must & 31 & 0.03 & 3 \\
would & 39 & 0.04 & 4 \\
shall & 1 & 0.00 & 1 \\
\hline Total & 4351 & 3.95 & 386 \\
\hline
\end{tabular}

The frequency list generated reveals interesting patterns in data. All nine central modal verbs are used in CLEO. There is a significant difference in the use of the various modal verbs. The modal verb will is greatly used by the writer compared to the other modal verbs. Will accounts for 76.46 per cent of total modal verbs occurrences. The least used modal verb form is shall accounting for 0.04 per cent of the total modal verbs. The total occurrence of modal auxiliary verbs is 4.80 per cent of the total 57,654 word token in the CLEO corpus.

In all three magazines, the modal auxiliary verb will has the highest frequency compared to other modal auxiliary verbs. This is similar to the findings by Kennedy (2002) who reported that the modal frequent modal will accounts for almost $23 \%$ of all modal tokens in the British National Corpus. May is the second top modal auxiliary verb used. Both modal auxiliary verbs are modals of probability. Will can be used to refer to future time or it can be used to mean volition or prediction (Biber et al, 1999). In horoscopes, will refers to future time and also prediction and some volition. On the other hand, shall is the least frequent modal verb used. This is supported by Coates (1983) and Quirk et al (1985) that shall is far less frequently used in contemporary English compared to would, will, could and can.

\section{The Functions of Modal Auxiliary Verbs}

Each modal auxiliary verbs used by the writer has different functions. To identify the different functions of the modals, sentences which contain modals were listed using 
concordance and sorted according to similar modals. Then, the modals were analysed and tabulated according to their functions as stated in the Curriculum specifications for English language (Malaysian Curriculum Specification, 2003). The functions of the modal auxiliary verbs are categorised as modals of ability, modals of probability and modals of necessity/ certainty or obligation. Table 5 shows the aggregated counts of modal use and function in horoscopes in the three magazines. From the table, it is shown the modals or probability is far more often used in horoscope, followed by modals of ability and modals of necessity and obligation.

Table 5

Aggregated counts of modal use and function

\begin{tabular}{|c|c|c|c|c|c|c|}
\hline Modals & QEO & $\begin{array}{l}\text { Women's } \\
\text { Weekly }\end{array}$ & Female & $\begin{array}{c}\text { Total } \\
\text { occurrences }\end{array}$ & $\%$ & $\begin{array}{l}\text { Occurrence } \\
\text { perten } \\
\text { thousand } \\
\text { words }\end{array}$ \\
\hline $\begin{array}{l}\text { Modals of Ability } \\
\text { (can, could) }\end{array}$ & 357 & 182 & 76 & 615 & 0.56 & 56 \\
\hline $\begin{array}{l}\text { Modals of Probability } \\
\text { (will, would, may, } \\
\text { might, shall) }\end{array}$ & 2365 & 790 & 417 & 3572 & 3.24 & 32 \\
\hline $\begin{array}{l}\text { Modals of } \\
\text { Necessity//Obligation } \\
\text { (should, must) }\end{array}$ & 48 & 81 & 35 & 164 & 0.15 & 15 \\
\hline TOTAL & 2770 & 1053 & 528 & 4351 & 3.95 & 103 \\
\hline
\end{tabular}

\section{Modals of Ability}

Table 6

Modals of ability in different magazines

\begin{tabular}{lcccc}
\hline \multirow{2}{*}{ Modals } & \multicolumn{2}{c}{ Can } & \multicolumn{2}{c}{ Could } \\
\cline { 2 - 5 } & ability & possibility & ability & possibility \\
\hline CLEO & 143 & 20 & 34 & 160 \\
Women's Weekly & 94 & 20 & 4 & 70 \\
Female & 37 & 22 & 6 & 10 \\
\hline Total (count) & 274 & 62 & 44 & 240 \\
\hline Total (\%) & $81.55 \%$ & $18.45 \%$ & $15.49 \%$ & $84.51 \%$ \\
\hline
\end{tabular}

The modals of ability is demonstrated by the modals can and could. The feature of the function of ability is that the subject is animate and has the potential to perform actions or abilities (Coates, 1983). The meaning of can is commonly glossed by "be able to". Could functions as the past tense form of possibility, ability and permission.

Out of the 274 uses of can, 81.55 per cent were used to express "ability" and $18.45 \%$ were used to express "possibility". The modal could found in the corpus is more often used to show possibility. This is shown from the data where 84.51 per cent of could is used to show possibility. This is due to the context the modal 
auxiliary verb is used. In horoscopes, the writer tries to predict. Thus, there is vast possibility and nothing is definite. The functions of the modal can as listed by the CDC (Malaysian Curriculum Specification, 2003), are ability, possibility and permission. According to Hoye (1997), the permission/possibility/ability modals express the writer's judgement. In the context of horoscope, the modal could is used more for possibility, compared to ability and permission. On the other hand, the modal can is used more frequently for ability rather than possibility or permission.

Examples of can that shows ability:

The only person who can make a big difference to your life is you. (CLEO 0111)

Remind yourself that you can work hard and play as hard too. (Female, 0612)

Examples of can that shows possibility:

A competitive streak can be healthy. (CLEO, 0611)

This can be a good thing. (Female, 0512)

Example of could that shows ability:

Short trips will lead to more adventure than you could anticipate. (CLEO, 0611)

Example of could that shows possibility:

Your flighty nature could prove disastrous to your relationship. (Female, 1012)

\section{Modals of Probability}

Table 7

Modals of probability in different magazines

\begin{tabular}{lccccc}
\hline & \multicolumn{2}{c}{ Possibility } & \multicolumn{3}{c}{ Prediction/volition } \\
\cline { 2 - 6 } & may & might & will & would & Shall \\
\hline CLEO & 223 & 11 & 2118 & 12 & 1 \\
Women's Weekly & 160 & 23 & 597 & 8 & 0 \\
FEMALE & 127 & 23 & 248 & 19 & 0 \\
\hline Total & 510 & 57 & 2963 & 39 & 1 \\
\hline
\end{tabular}

Table 8

Functions of the modal will and would

\begin{tabular}{lcccc}
\hline & \multicolumn{2}{c}{ will } & \multicolumn{2}{c}{ Would } \\
\cline { 2 - 5 } & prediction & volition & prediction & volition \\
\hline CLEO & 2013 & 105 & 12 & 0 \\
Women's Weekly & 588 & 9 & 8 & 0 \\
Female & 228 & 20 & 17 & 2 \\
\hline Total (count) & 2829 & 134 & 37 & 2 \\
\hline Total (\%) & 95.48 & 4.52 & 94.87 & 5.13 \\
\hline
\end{tabular}

Modals of probability indicate future event. The most frequent modal of probability in the horoscopes of all three magazines is the modal will. Will is used to show 
prediction or volition. The degree of certainty is strong. Volition refers to the free will of a person to do something. The sense of willingness usually involves animate subjects and some physical actions or events taking place in the future. However, Biber et al. (1999) stressed that the distinction between volition and prediction is often blurred. The analysis of will shows that the prediction function is far greater than the volition function in the context of horoscope. Most uses of will (95.48 per cent) is used to show prediction compared to 4.52 per cent used for volition whereas 94.87 per cent of would is used to show prediction compared to 5.13 per cent to show volition.

The modal will functions to refer to future time and also prediction. Whether for futurity or prediction, the degree of certainty is strong. Will expresses a confident statement. The statements are not necessarily true but they are presented as valid by the writers. Besides, many of the sentences are attached with a conditional clause. Until you shed your old baggage, it'll be hard to love and have fun. This shows that the prediction is dependent on the fulfilment of future conditions. The use of temporal clause also adds to the certainty of prediction. By the $27^{\text {th }}$, you'll have respect and romance.

The modal may indicates permission or possibility. Longman Spoken and Written English (KSWE) Corpus states that may is rarely used to indicate probability (Biber et al., 2002). However, in the data, the modals may indicate possibility and not permission. Might, like may, has the primary function to express possibility. However, may and might demonstrate the writer's lack of confidence in the truth of what is expressed. It indicates a certain level of uncertainty in the truth that is expressed.

Shall is the least used modal auxiliary verb in the corpus data. Romer (2004) found that shall is very frequently used in questions in BNC and is usually accompanied by a first person subject $/$ or we. That might be the reason shall is the least used modal auxiliary verb used in the corpus data. In the corpus data, the most frequent pronoun is the second person pronoun you.

Examples of will that shows prediction:

The $26^{\text {th }}$ will bring new clarity and direction. (CLEO, 0811)

Business dealing will be lucrative as you receive unexpected financial gains. (Female, 0513)

Examples of will that shows volition:

He will know how to push hard enough to get what he wants at work. (CLEO 0211) Before you lose your cool, bear in mind that it's only a phase and he will snap out of it in due time. (Female, 0612)

The modal may indicates permission or possibility. Longman Spoken and Written English (KSWE) Corpus states that may is rarely used to indicate probability (Bieber et al., 2002). However, in the data, the modals may indicate possibility and not permission. Might also shows possibility.

Examples of may that shows possibility: 
You may give a lot but it's rarely for nothing and you have high expectations! (CLEO, 0711)

A close friend may be down in the dumps and need a reboot. (Female, 1112)

Example of might that shows possibility:

There might be some tension with your partner. (Female, 0111)

Shall is the least used modal auxiliary verb in the corpus data. Romer (2004) found that shall is very frequently used in questions in BNC and is usually accompanied by a first person subject I or we. That might be the reason shall is the least used modal auxiliary verb used in the corpus data. In the corpus data, the most frequent pronoun is the second person pronoun you.

Example of shall that shows possibility:

Like what they say, ask and you shall receive. (CLEO, 0212)

\section{Modals of Necessity/Obligation}

Table 9

Modals of necessity/obligation in different magazines

\begin{tabular}{lcc}
\hline & \multicolumn{2}{c}{ Necessity/obligation } \\
\cline { 2 - 3 } & should & must \\
\hline CLEO & 31 & 17 \\
Women's Weekly & 68 & 15 \\
FEMALE & 34 & 1 \\
\hline Total & 133 & 33 \\
\hline
\end{tabular}

The modals categorised as modals of necessity and obligation include should and must. Table 9 shows the frequency of modals of necessity/obligation. Out of the two modal verbs, the modal should is more frequently used. The obligation/necessity modals emphasize social obligation to compel readers to react. Besides, the obligation/necessity modals strengthen the writer's statements and at the same time establish objectivity (Meyer, 1997). Both central modals which express obligation and necessity are infrequent in the horoscope data compared to other modals. This is not surprising because modals of obligation and necessity are much less frequent in spoken English than modals of probability and modals of probability and ability/permission/possibility (Bieber et al., 1999). The modal should connotes obligation or duty at its strongest and at its weakest refers to offering advice or giving suggestion. Should that occurred more frequently is of "weak obligation". The modal should is regarded as more polite (Bieber et al., 1999). In horoscopes, the writer tries to be more polite and less forceful when giving advice.

Example of should that shows necessity/obligation:

Join ventures should be avoided and if you are already in one, proceed with caution. (CLEO, 1011) 
Table 5 shows the most frequently used modals are modals of probability. The most frequently used modal is the modal will. This is due to the nature of the text which is horoscopes that predicts one's future and gives advice to readers. Horoscope writers greatly utilise modals of probability to influence readers. The low frequencies of the modals of necessity and obligation do not signify its lack of importance. It is still wisely used by horoscope writers to convince the readers.

\section{Conclusion and Implications}

This study investigated the use of modal auxiliary verbs in horoscope. From the findings, it is concluded that the most frequent lexis used in horoscope is the pronoun you which is used to establish rapport with readers in order to give advice and convince them. The most frequent modal auxiliary verb used in horoscope is the modal will followed by may which is evident in all these magazines. Both will and may are modals of probability used to predict. Modals of probability that includes will, would, may, might and shall are more frequently used by writers in all three horoscopes to predict and state possible future events. The least used modals are modals of necessity and obligation. A more polite approach is employed by writers to give suggestion and advice.

The frequency list generated from this study is useful for teachers because it helps teachers to decide which item to emphasise when using horoscopes in classroom teaching. As the frequency list shows that the most frequent modals are modals of probability, horoscope entries could be utilised to teach the related modal auxiliary verbs such as will, would, may, might and shall. High occurrences of modals of probability and modals of ability indicate frequent repetition of words. When a structure is taught repeatedly, it enhances students' memory and understanding of the matter. Repetition of words is essential to acquire a word. When reading, words are likely to be remembered if they are read at last seven times over spaced intervals (Thornbury, 2004). The vast occurrence of modals in horoscope provides students with ample exposure to the language to gain sufficient input.

The use of horoscopes could help overcome the difficulties students face in using modals. It is found that students have difficulties when it comes to the meaning and function of modals, due to the lack of an equivalent modal verb system in Bahasa Melayu, hence hindering the learning of modals (Mohammad Ismail Abdul Kader, Begi, \& Vaseghi, 2013). Incorporating horoscopes which contains high number of modal auxiliary verbs in the language classroom could raise students' awareness of using modals accurately. Engaging topics in horoscope entries would also attract learners' interest and make them realise the relevance of modal auxiliary verbs to them.

Furthermore, the inclusion of authentic texts such as horoscopes can supplement the existing Malaysian textbooks. As corpus studies of Malaysian textbooks found no implicit teaching of modals would, could and shall in the entire lower secondary level (Mukundan \& Khojasteh, 2011; Khojasteh \& Kafipour, 2012), various examples found in horoscope entries could reinforce students' learning of the forms and functions of modal auxiliary verbs. The concordance lines generated 
from concordance could be used to show students the appropriate use of modal auxiliary verbs in real-life context.

Horoscopes should be treated as an authentic reading text. Authentic text illustrates the grammar being taught (Gardner, 2008) and they can be motivating because it proves that language is used in real life for real purposes (Nuttall, 1996). Therefore, it is important that modal auxiliary verbs are taught in a meaningful context (Celce-Murcia \& Larsen-Freeman, 1999). Teachers of second language learners should select or adapt appropriate teaching materials so that grammar is taught in an entertaining way where students are motivated to learn, understand and are able to apply them. Horoscopes can be used as an alternative teaching material in the classroom when there is a need to teach certain language items such as modal auxiliary verbs.

Reading various texts is beneficial for students although horoscopes are mostly written for female readers. The common topics discussed such as love, relationships, friendships, family, self-control and work are general topics which both male and female learners can relate to. Therefore, horoscopes should not be seen as a gender biased material. Incorporating horoscopes in classrooms does not require students to believe in horoscopes. Instead, it is an opportunity to encourage students to read for pleasure in a non-threatening environment.

Learning should be meaningful, in which students learn and are able to transfer knowledge to real life situations. Teachers can assign communicative tasks that require students to use modal auxiliary verbs when completing the task. One example is role play. Students can be given situations to role play; in which they give advice and make predictions. The role play can be carried out in the form of conversation or through advice column. Another activity teachers can use in the classroom to teach will for predictions is "fortune teller" or "fortune cookies". One person will be the fortune teller and the other person is the client. Students can carry out the role play, making use of modals in conversation or write out fortunes for each other, applying the use of modal verbs.

To promote noticing of grammatical structure, teachers are encouraged to bring students' attention to modal auxiliary verbs. A way to promote students' awareness of a particular grammatical structure is to highlight it in a text (CelceMurcia \& Larsen-Freeman, 1999) and in the case of modal auxiliary verbs, through horoscopes. Students can be asked to circle all the modal auxiliary verbs found in the text to draw students' attention to the occurrences of modal auxiliary verbs. This is because enhancing input is an effective way to focus students' attention on grammatical structure (Celce-Murcia \& Larsen-Freeman, 1999). Consequently, the teacher can use a consciousness raising task where students induce a grammatical generalisation from the text. Teachers can assign students to work in groups or individually to induce the rules and functions from the modal auxiliary verbs that were circled in the text. The 21st century education is discovery learning as opposed to retelling of rules. A table with the functions of modals can be provided. Students can be asked to list the modal auxiliary verbs and tick the functions it best fits. This includes ability, obligation, necessity, possibility, probability, certainty, request, permission, advice, suggestion or warning. Students will find that functions overlap and the same modal auxiliary verb can have multiple meanings. 
Lack of exposure to modal auxiliary verbs may cause problems in understanding them and result in the inability to use them in writing and speech. Problems using modals may result in difficulty in conveying intended interpersonal meaning. In communication, learners need to select the appropriate modal auxiliary verbs they use to prevent miscommunication. Therefore, with empirical findings that horoscope contains high frequency of modal auxiliary verbs, teachers can use horoscopes as an alternative in their classroom teaching in order to expose students with modal auxiliary verbs where students are confronted with natural language. Both teachers and students can gain insights from this study.

\section{References}

Biber, D., Conrad, S., \& Reppen, R. (1998). Corpus linguistics: Investigating language structure. New York, NY: Cambridge University Press.

Biber, D., Johansson, S., Leech, G., Conrad, S., \& Finegan, E. (1999). Longman grammar of spoken and written English. Harlow, UK: Pearson.

Biber, D., Conrad, S., \& Leech, G. (2002). Longman students grammar of spoken and written English. Essex, UK: Pearson Education.

Celce-Murcia, M., \& Larsen-Freeman, D. (1999). The grammar book: An ESL/EFL teacher's course (2nd edition). Boston, MA: Heinle \& Heinle Publishers.

Chang, Y. L. (2002). Horoscopes what they don't say: A lexical and linguistic analysis. (Unpublished Master's thesis): University of Lancaster, Lancaster, UK.

Coates, J. (1983). The semantics of the modal auxiliaries. London, UK: Croom Helm.

Engler, S. L. (2003). Identity formation: Women's magazine language. (Unpublished undergraduate senior honors thesis) Ball State University, Indiana. Retrieved from https://cardinalscholar.bsu.edu/handle/handle/190237

Ferris, D. R. (2002). Treatment of errors in second language student writing. Ann Arbor, MI: The University of Michigan Press.

Hoye, L. (1997). Adverbs and modality in English. London, UK: Longman.

Hughes, R., \& Heah, C. (1993). Common errors in English: Grammar exercise for Malaysians ( $2^{\text {nd }}$ ed.). Selangor, Malaysia: Fajar Bakti.

Gardner, S. (2008). Changing approaches to teaching grammar. ELTED, 11, 39-44.

Guariento, W., \& Morley, J. (2001). Text and task authenticity in the EFL classroom. ELT Journal 55(4), 347-353.

Kennedy, G. (2002). Variation in the distribution of modal verbs in the British National Corpus. In Reppen, R., Fitzmaurice, S. M., \& Biber, D (Eds.). Using corpora to explore linguistic variation. Philadelphia, PA: John Benjamins Publishing Co.

Khojasteh, L., \& Kafipour, R. (2012). Non-empirically based teaching materials can be positively misleading: A case of modal auxiliary verbs in Malaysian English language textbooks. English Language Teaching, 5(3), 62-72.

Khojasteh, L., \& Reinders, H. (2013). How textbooks (and learners) get it wrong: A corpus study on modal auxiliary verbs. Applied Research on English Language, $2(1), 33-44$

Liao, Y., \& Liao, T. (2009). Modal verbs for the advice move in advice columns. In O. Kwong (Ed.), Proceedings of the 23rd Pacific Asia Conference on Language, 
Information and Computation, Vol. 1 (pp. 307-314). Hong Kong, Hong Kong: City University of Hong Kong.

Malaysian Curriculum Specification. (2003). Form 4 English Language Curriculum Specifications. Malaysian Ministry of Education. Kuala Lumpur.

Martinez, A. G. (2002). Authentic materials: An overview Karen's linguistic issues. Retrieved from http://www.Telus.Net/linguistic issues authentic materials.html

McCarthy, M. (1991). Discourse analysis for language teachers. London, UK: Cambridge University Press.

McCarthy, M., \& Carter, R. (2014). Language as discourse: Perspectives for language teaching. Routledge.

McLoughlin, L. (2000). The language of magazines. London, UK: Routledge.

Meyer, P. (1997). Hedging strategies in written academic discourse: Strengthening the argument by weakening the claim. In R. Markkanen, \& H. Schroeder (Eds.), Hedging and discourse: Approaches to the analysis of a pragmatic phenomenon in academic texts. (pp. 21-41). Berlin, Germany: Walter de Gruyter.

Mohammad Ismail Abdul Kader, Begi, N., \& Vaseghi, R. (2013). A corpus-based study of Malaysian ESL learners' use of modals in argumentative Compositions. English Language Teaching, 6(9), 146-157.

Mukundan, J., \& Khojasteh, L. (2011). Modal auxiliary verbs in prescribed Malaysian English Textbooks. English Language Teaching, 4(1), 79-89.

Nuttall, C. (1996). Teaching reading skills in a foreign language (New Edition). Oxford, UK: Heinemann

Quirk, R., Greenbaum, S., Leech, G., \& Svartvik, K. (1985). A comprehensive grammar of English language. London, UK: Harlow.

Reppen, R., \& Simpson, R. (2002). Corpus linguistics. In N. Schmitt (Ed.) An introduction to applied linguistics. (pp. 92-111). London, UK: Arnold.

Romer, U. (2004). A corpus-driven approach to modal auxiliaries and their didactics. In J. Sinclar (Ed.) How to Use Corpora in Language Teaching. Amsterdam, The Netherlands: John Benjamins.

Rosli, T., \& Edwin, M. (1989). Error analysis of form four English compositions. The English Teacher, 28.

Thompson, M. (2002). Modals in English language teaching. Retrieved from: http://telusplanet.net/linguisticsissues/modalsinteaching.html

Tomlinson, B. (1998). Materials development in language teaching. Cambridge, UK: Cambridge University Press.

Thornbury, S. (2004). How to teach grammar. Selangor, Malaysia: Pearson Education Limited.

Tognini-Bonelli, E. (2001). Corpus linguistics at work. Philadelphia, PA: John Benjamins.

Vethamani, M. E., Umi Kalthom Abd Manaf, \& Omid Akbari (2010). Students' use of modals in their written work: Compensation strategies and simplification features. Studies in Languages and Language Teaching Journal, 14(2), 11-15.

Vine, B. (2004). Modal verbs in New Zealand English directives. Nordic Journal of English Studies, 3(3), 205-220. 
Watts, R. J. (1984). An analysis of epistemic possibility and probability. English Studies 65, 129-140.

Wynne, M. (2005). Developing linguistic corpora: A guide to good practice. Oxford, UK: Oxbow Books.

Zareva, D. (2013). Values: Written in the stars: Prompted by the media. Paper presented at the $20^{\text {th }}$ ICC Conference, Sofia University, Bulgaria. 